\title{
Gazownie komunalne Poznania i Lwowa na początku XX w. Próba charakterystyki i porównania ich rozwoju
}

\author{
Municipal Gasworks in Poznań and Lwów \\ in the Early 20 ${ }^{\text {th }}$ Century. An Attempt to Characterize \\ and Compare Their Development
}

The Poznań and Lwów gasworks were established in the 1850s; the former being an urban enterprise, the latter a private company. At the beginning of the 20th century, the gasworks and the entire gas infrastructure in Lwów were seriously outdated as compared to Poznań in terms of the volume of production and technology. After the municipalization of the plant in 1898, Galicia's capital quickly began to reduce a backlog using the effects of technical progress in Europe. As part of the modernization and expansion of both gasworks in the first decade of the 20th century, modern water-gas plants with Humphreys \& Glasgow systems were commissioned in Poznań (1900) and Lwów (1906). Moreover, the gas network and public lighting system were intensively developed in both cities. In 1910, 11.3 million cubic meters of gas flowed into the municipal network in Poznań, whereas 6.1 million cubic meters did so in Lwów. The number of gas street lights amounted to 3456 and 3541, respectively. In both cities, major extensions of their gasworks were planned in the very years preceding the outbreak of World War I. In Poznań, the investment was implemented to a large extent during World War I, when a unique and innovative Koppers retort house and a dry-seal gas holder with a capacity of 50 thousand cubic meters were built. In Lwów, due to the Russian occupation of the city between 1914 and 1915, ultimately the works had to be stopped. Due to wartime hardships, the planned Glover-West vertical retort house was eventually replaced by the Dessau vertical retort furnace. The retort house was completed in 1917, but the rest of the investment was finalized in the first years of the Second Polish Republic. Nevertheless, when the Partitions of Poland ended, both gas plants were among the largest and most modern in terms of technology in the country, in which their directors at the time, Hans Mertens in Poznań and Adam Teodorowicz in Lwów, had considerable merit. 
Keywords: Lwów, Poznań, gasworks, water-gas plant, gas street lighting, 19th century

Słowa kluczowe: Lwów, Poznań, gazownia, zakład gazu wodnego, oświetlenie gazowe, XIX w.

Poznań i Lwów, zdawać by się mogło, że dwa różne światy, wszakże to miasta położone na przeciwległych krańcach przedrozbiorowej Polski, na zachodzie i daleko na wschodzie I Rzeczypospolitej'. A jednak, pomimo tej odległości, pomimo istnienia i funkcjonowania w dwóch różnych systemach państwowych względnie zaborach, doszukać się można pewnych analogii, widocznych choćby w drodze rozwojowej czy rozwiązaniach technologicznych stosowanych w municypalnych gazowniach obu ośrodków. Przy czym pamiętać trzeba, że mamy tu do czynienia z dużymi miastami o charakterze stołecznym: Poznaniem jako stolicą Wielkiego Księstwa Poznańskiego w zaborze pruskim oraz Lwowem, czyli stolicą przeszło dwukrotnie większego kraju koronnego przedlitawskiej części monarchii habsburskiej, mianowicie Galicji i Lodomerii.

Tytułem wstępu nadmienię tylko, że choć obydwa miasta były stolicami dużych regionów w dwóch różnych zaborach, to jednak ich XIX-wieczny rozwój determinowały dwie diametralnie odmienne rzeczywistości, i bynajmniej nie myślę tutaj o rzeczywistości czysto politycznej albo gospodarczej, ale o uwarunkowaniach militarnych. Poznań to miasto ujęte monstrualnymi okowami twierdzy poligonalnej, zastępowanej w ostatniej tercji XIX w. stopniowo umocnieniami systemu fortowego, a likwidowanej fizycznie dopiero wraz z nadejściem XX w. ${ }^{2}$ Dzięki temu możliwy stał się wreszcie nieskrępowany rozwój przestrzenny grodu nad Wartą oraz zauważalny przyrost liczby ludności. W tym samym czasie Lwów był miastem otwartym, pozbawionym umocnień utrudniających jego rozwój. Efektem tego - jak łatwo się domyślić - był swobodny rozwój urbanistyczny, od ostatniej dekady XIX w. zintegrowany z wzrastającym szybko zaludnieniem³. Przy czym podkreślić trzeba, że intensywne działania modernizacyjne w sferze szeroko rozumianej nowoczesnej miejskiej infrastruktury technicznej zaczęły postępować we Lwowie intensywnie dopiero od końca XIX w., a de facto od momentu organizacji Powszechnej Wystawy Krajowej w 1894 r. Była ona pierwszym, tak imponującym efektem zmian w świadomości ludzi odpowiedzialnych za wybór optymalnego modelu rozwoju społeczno-gospodarczego Galicji, w tym i jej stolicy ${ }^{4}$. Wtedy to bowiem władze samorządowe Lwowa, wzorem innych dużych miast monarchii naddunajskiej, doszły do wniosku, że to właśnie samorząd musi brać aktywny udział w budowie nowoczesnej infrastruktury technicznej miasta. Efektem tej aktywności

1 Niniejszy artykuł powstał w ramach grantu Narodowego Centrum Nauki w Krakowie pt. Miejska infrastruktura techniczna Lwowa w latach 1870-1918 (UMO-2014/15/B/HS3/02493).

2 Szerzej zob.: J. Biesiadka, A. Gawlak, S. Kucharski, M. Wojciechowski, Twierdza Poznań. O fortyfikacjach miasta Poznania w XIX i XX wieku, Poznań 2006; J. Skuratowicz, Architektura Poznania 1890-1918, Poznań 1991; Z. Pałat, Architektura a polityka. Gloryfikacja Prus i niemieckiej misji cywilizacyjnej w Poznaniu na początku XX wieku, Poznań 2011.

3 M. Kowalczuk, Rozwój terytorialny miasta, [w:] Miasto Lwów w okresie samorządu, Lwów 1896, s. 313-321; K. Pawłowski, Narodziny miasta nowoczesnego, [w:] Sztuka drugiej połowy XIX wieku. Materiały sesji Stowarzyszenia Historyków Sztuki, Łódź listopad 1971, Warszawa 1973, s. 51-78.

4 J. Wnęk, Rozwój ideologii przemysłowej w Galicji 1866-1918, Warszawa 2015, s. 81-95; W. Puchta, Powszechna Wystawa Krajowa we Lwowie w 1894 roku, Wrocław 2016, s. 227-267. 
stała się jedyna na polskich kresach wschodnich sieć tramwajów elektrycznych (1894 r.), elektrownia miejska (1900 r.), centralny system wodociągowy (1901 r.) etc. ${ }^{5}$ Notabene podobnie było też w Poznaniu, choć tutaj samorząd municypalny swój udział w kształtowaniu warunków cywilizacyjnych mieszkańców zaczął akcentować już nieco wcześniej, o czym świadczyć może choćby centralny system wodociągowy, uruchomiony w 1866 r., ale wprowadzenie tramwajów elektrycznych nastąpiło dopiero w 1898 r., zaś energia elektryczna z miejskiej elektrowni popłynęła w grodzie nad Wartą w 1904 r. ${ }^{6}$

O owych XIX-wiecznych uwarunkowaniach obu miast wspominam nieprzypadkowo, gdyż to właśnie liczba ludności miała istotne znaczenie najpierw dla powstania zakładu gazowniczego, a później wielkości zużycia gazu, czyli jego produkcji. Ta ostatnia determinowała z kolei zastosowanie określonych rozwiązań technologicznych oraz odpowiednią skalę przestrzenną kompleksu produkcyjnego. Oczywiście nie tylko ludność decydowała o rozmiarach zużycia gazu i poziomie technicznym zakładu, lecz także rozległość miasta i związana z tym liczebność latarni oświetlenia publicznego, a także zużycie gazu do innych celów, np. na potrzeby kolei czy z przeznaczeniem do funkcji przemysłowych albo grzewczych, odzwierciedlające poniekąd też zamożność mieszkańców oraz stopień rozwoju przemysłu i rzemiosła w mieście. Niezależnie jednak od tego, to właśnie liczba ludności stanowiła jeden z fundamentalnych czynników determinujących wielkość produkcji gazu, a zatem i skalę kompleksu gazowniczego. Spoglądając tedy z takiej perspektywy na obydwa miasta, przyznać trzeba, że Lwów był jednak znacznie większy od Poznania, licząc w 1890 r. niemal 128000 mieszkańców, w 1900 r. prawie 160 000, zaś w 1910 r. już 206 000. Ujęty pierścieniem fortyfikacji Poznań, w identycznym czasie zamieszkiwało znacznie mniej ludności, czyli niespełna 70000 w 1890 r., ale w 1900 r. - po wcieleniu w granice miasta kilku osad podmiejskich - już 117 000, zaś w 1910 r. prawie 155 0007. Paradoksalnie jednak, choć ludnościowo mniejszy, to jednak gospodarczo i ekonomicznie silniejszy był Poznań, o czym świadczy znacznie większe zapotrzebowanie na gaz, uwidocznione w tabeli na końcu artykułu.

Wprawdzie obydwa miasta sporo się różniły, ale dostęp do gazu świetlnego uzyskały niemal w tym samym czasie. W Poznaniu zbudowana na własny rachunek przez samorząd miejski gazownia ruszyła 14 listopada 1856 r. Jej projektantem i budowniczym był niemiecki inżynier angielskiego pochodzenia dr inż. John Moore z Berlina. Położony w pobliżu Rynku i nad Wartą zakład gazowniczy od początku funkcjonował jako przedsiębiorstwo komunalne, a do produkcji gazu wykorzystywał najpierw angielski, a później górnośląski węgiel kamienny8. We Lwowie władzom samorządowym zabrakło wizji, a może odwagi

5 S. Hoszowski, Ekonomiczny rozwój Lwowa w latach 1772-1914, Lwów 1935, s. 59-61, 99-105; T.Ł. Sroka, Rada Miejska we Lwowie w okresie autonomii galicyjskiej 1870-1914, Kraków 2012, s. 132-133, 332-333; D. Hołuj, Samorząd miejski Krakowa i Lwowa w okresie autonomii galicyjskiej, „Zeszyty Naukowe Uniwersytetu Ekonomicznego w Krakowie" 2013, nr 917, s. 98, 102.

6 J. Czwojdziński, Zaopatrzenie Poznania w wodę, [w:] Wielka księga miasta Poznania, Poznań 1994, s. 612; T. Dohnalowa, Rozwój transportu w Wielkopolsce w latach 1815-1914, Warszawa - Poznań 1976, s. 182.

7 M. Kędelski, Stosunki ludnościowe w latach 1815-1918, [w:] Dzieje Poznania w latach 1793-1918, red. J. Topolski, Poznań 1994, t. 2, cz. 1, s. 226; K. Wnęk, L. Zyblikiewicz, E. Callahan, Ludność nowoczesnego Lwowa w latach 1857-1938, Kraków 2006, s. 31-32.

8 Szerzej o gazowni poznańskiej zob.: A. Dziurzyński, 75-lecie Gazowni Miejskiej w Poznaniu, "Gaz i Woda” r. 11, 1931, nr 12, s. 293-301; L. Łuczak, W blasku błękitnego płomienia. 150 lat gazowni w Poznaniu, Poznań 2006; M. Urbaniak, Miejskie zakłady przemysłowe Wielkiego Księstwa Poznańskiego. Gazownie, t. 2 - Katalog, Łódź 2011, s. 344-386; A. Zarzycki, Poznań. Gazownia w dziejach miasta. Tradycja i współczesność 1856-2012 Poznań 2013. 


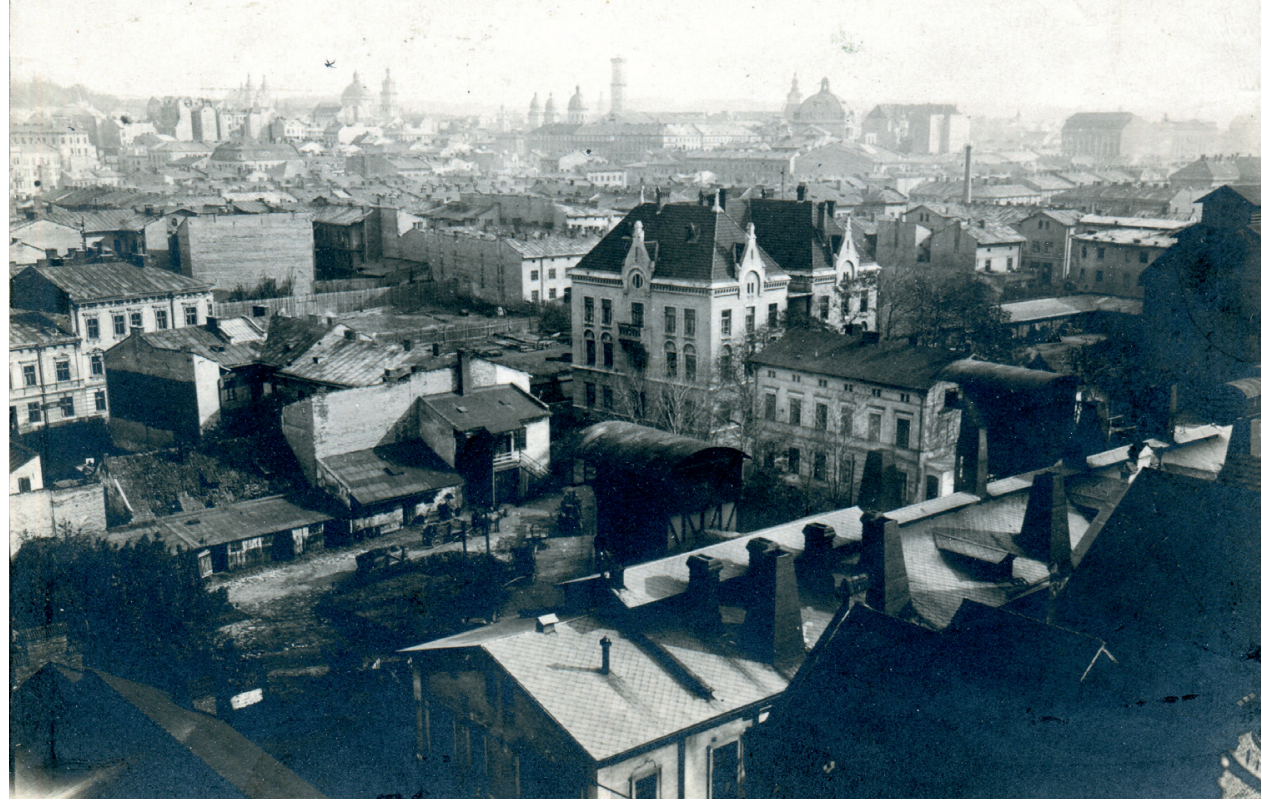

Widok gazowni Iwowskiej w latach międzywojennych, z przodu widoczny podłużny budynek starej piecowni poziomoretortowej (Źródło: zbiory Igora i Iriny Kotłobułatowych).

do podjęcia inwestycji na własny rachunek i zdecydowały się na stosunkowo częste w tym okresie partnerstwo publiczno-prywatne, zasadzające się w tym konkretnym przypadku na 25-letniej koncesji udzielonej firmie Niemieckie Gazowe Towarzystwo Kontynentalne (Deutsche Continental-Gas-Gesellschaft) z Dessau9. Na podstawie kontraktu Towarzystwo przeprowadziło budowę gazowni wraz z całą infrastrukturą oświetleniową Lwowa na własny koszt, ale później - przez 25 lat (z możliwością dalszego przedłużenia) - zyskiwało monopol na jej eksploatację i wyłączną sprzedaż gazu miastu oraz jego mieszkańcom. Umowę na budowę podpisano wprawdzie już w lutym 1856 r., lecz oświetlenie gazowe uruchomiono dopiero 21 maja 1858 r. Osobliwością gazowni lwowskiej było wytwarzanie gazu świetlnego w procesie suchej destylacji drewna brzozowego oraz sosnowego, które było tu surowcem znacznie tańszym, a przede wszystkim łatwiejszym w pozyskaniu aniżeli węgiel kamienny. Produkcję gazu na bazie węgla z kopalń górnośląskich podjęto dopiero w 1870 r., przechodząc tym samym na wytwórczość klasycznego gazu węglowego ${ }^{10}$.

Aż do września 1898 r. gazownia Iwowska wraz z całą infrastrukturą gazową pozostawała własnością Niemieckiego Gazowego Towarzystwa Kontynentalnego, co oznaczało, że władze Lwowa nie miały praktycznie żadnego wpływu na poziom rozwiązań

9 Szerzej o gazowni lwowskiej zob.: A. Teodorowicz, O rozwoju gazowni we Lwowie, „Przegląd Gazowniczy” r. I, 1921, nr 1, s. 3-10; idem, O rozwoju gazowni we Lwowie, "Przegląd Gazowniczy”, r. 1, 1921, nr 2, s. 26-29; por też: G. von Klass, 100 Jahre Deutsche Continental Gas-Gesellschaft. Düsseldorf 1855-1955, Düsseldorf 1955.

10 Dr. N. H. Schilling's Statistische Mittheilungen über die Gasanstalten Deutschlands, Österreichs und der Schweiz sowie einige Gasanstalten anderer Länder, München 1877, s. 304-305; Dr. N. H. Schilling's Statistische Mittheilungen über die Gasanstalten Deutschlands, Österreichs und der Schweiz sowie einige Gasanstalten anderer Länder, München 1896, s. 171; A. Teodorowicz, O rozwoju gazowni, nr 1, s. 3-4. 


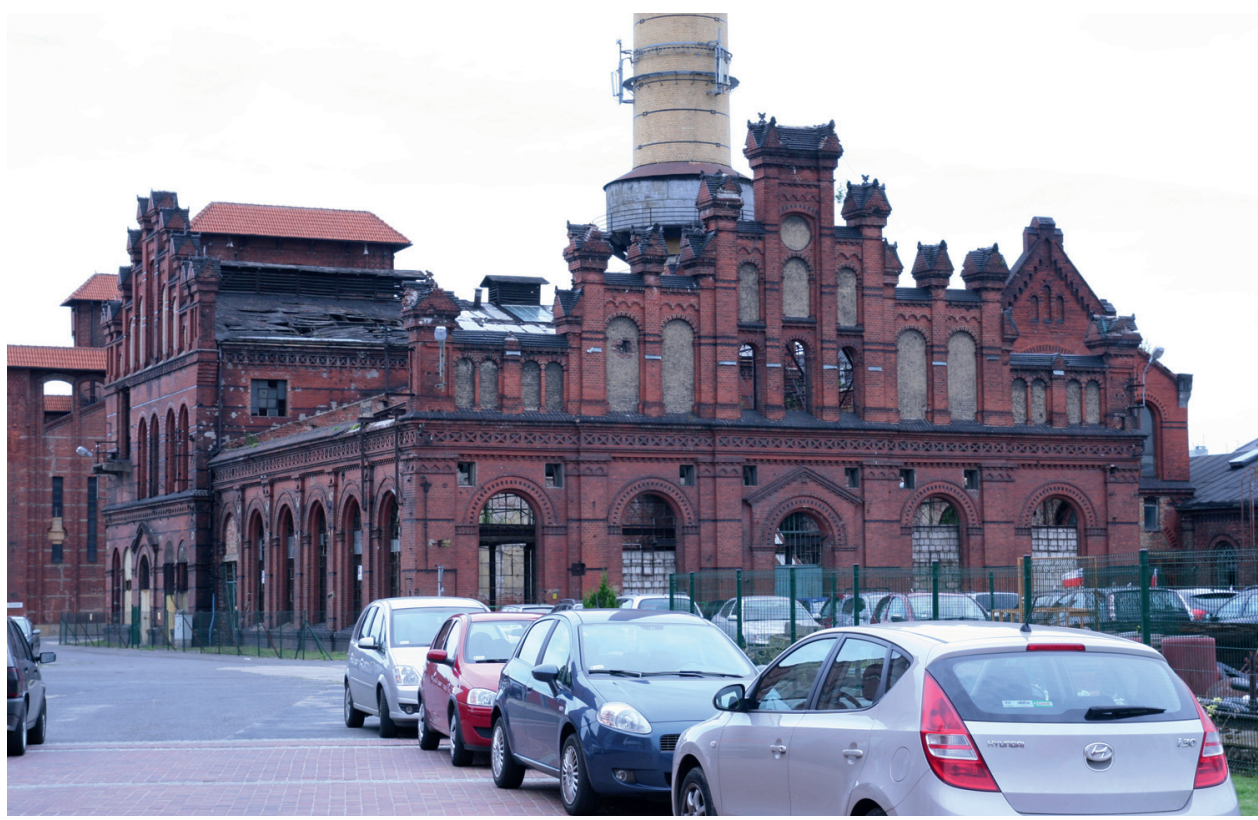

Budynek zakładu gazu wodnego w gazowni poznańskiej w 2012 r. (Źródło: M. Urbaniak).

technologicznych oraz wykorzystanie najnowszych zdobyczy techniki w gazownictwie na terenie miasta. Na przeszkodzie modernizacyjnym inwestycjom stał opór władz firmy z Dessau, nastawionej - jak łatwo się domyślić - przede wszystkim na czerpanie zysków, a nie wydatki inwestycyjne w lwowski zakład. Zresztą aż do lat dziewięćdziesiątych XIX w. potrzebę poważnej inwestycji ograniczano skutecznie, tłamsząc sztucznie popyt na gaz polityką jego wysokich cen, co z jednej strony prowadziło do ograniczania globalnej produkcji zakładu, z drugiej pozwalało unikać jego kosztownej, gruntownej rozbudowy. Wspominał o tym po latach Adam Teodorowicz, pisząc: „Do r. 1890 gazownia nie wykazuje prawie żadnego rozwoju, a wyrób gazu dochodzi zaledwie do $1.100 .000 \mathrm{~m}^{3}$ [rocznie - M.U.]". W kolejnych latach produkcja wprawdzie wzrastała, ale do końca prywatnej własności nie przekroczyła nigdy $2 \mathrm{mln}^{3} \mathrm{gazu}_{\text {rocznie }}{ }^{11}$. O skali zaniedbań dessauskiej spółki w sferze gazowej Lwowa doskonale świadczy fakt, że w chwili przejęcia zakładu przez samorząd w 1898 r., na terenie miasta płonęły tylko 862 latarnie gazowe, jednak w ciągu pierwszych pięciu lat miejskiego zarządu, do 1903 r., władze samorządowe ustawiły dodatkowo aż 1009 nowych latarni. Posłużyły one w głównej mierze do zastąpienia - powszechnych na pozbawionych sieci gazowej przedmieściach - latarni naftowych ${ }^{12}$.

W tym samym czasie w Poznaniu, sporo mniejszym przecież od Lwowa, ale dysponującym samorządowym zakładem, sytuacja wyglądała zgoła odmiennie. Tutaj produk-

11 A. Teodorowicz, O rozwoju gazowni, nr 1, s. 5.

12 Archiwum Państwowe Obwodu Lwowskiego we Lwowie [Dierzhavnyi Arkhiv Lvivskoi Oblasti - DALO], fond 3, op. 1, spr. 4980, korespondencja dyrekcji gazowni z Iwowskim Magistratem z lat 1904-1905; fond 599, op. 1 , spr. 5, sprawozdanie A. Teodorowicza w sprawie powiększenia gazowni miejskiej z 22 VI 1905. 


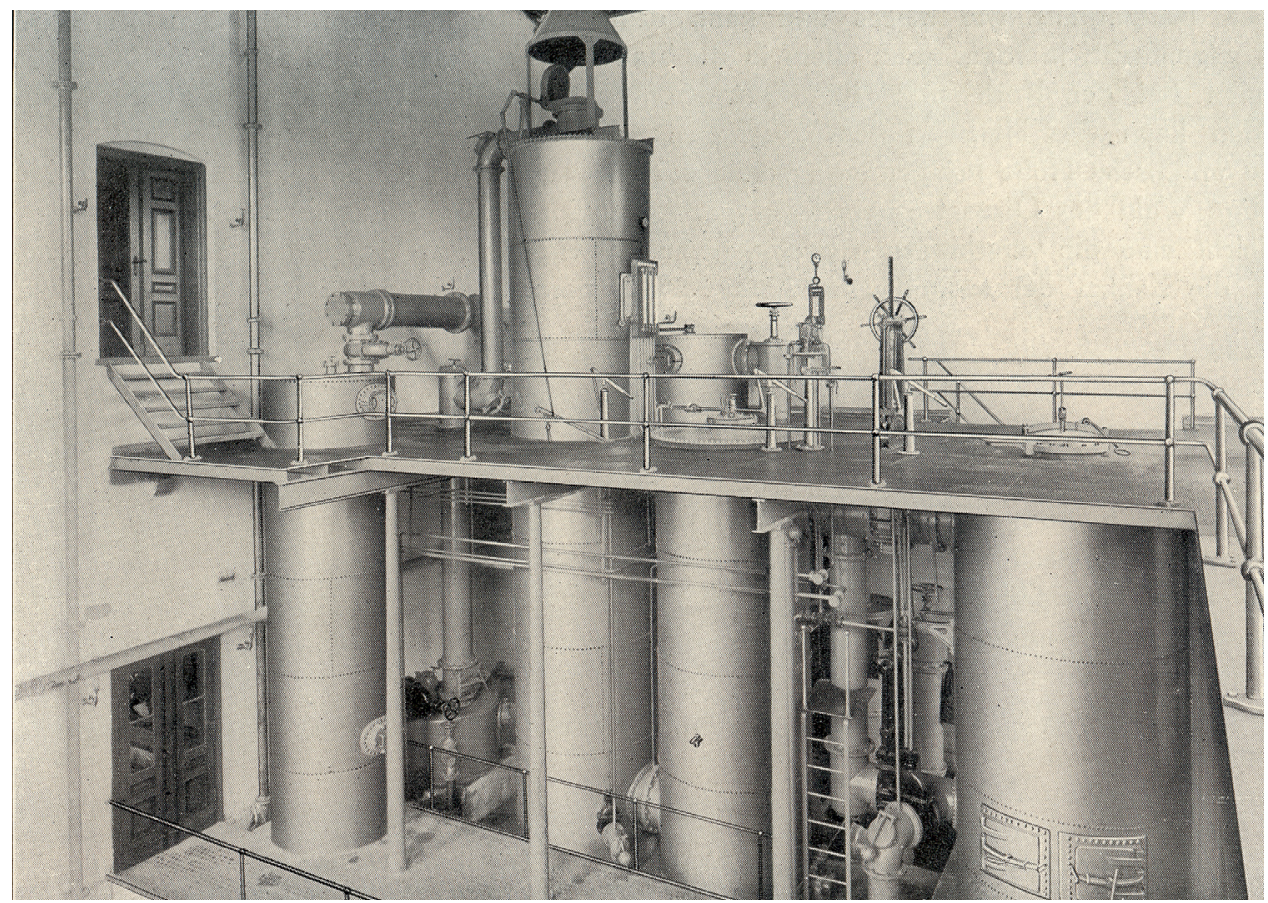

Urządzenia firmy Humphreys \& Glasgow do produkcji gazu wodnego w Poznaniu ok. 1910 r. (Źródło: Gasanstalten. Julius Pintsch Aktiengesellschaft, Berlin 1915).

cja gazu w roku budżetowym 1898 sięgnęła już 4,1 mln $\mathrm{m}^{3}$ gazu, a liczba gazowych latarni publicznych wynosiła $1377^{13}$. Do tego dochodził również fakt, że zakład gazowniczy o dobowej zdolności produkcyjnej rzędu $15000 \mathrm{~m}^{3}$ coraz częściej był przeciążany i z trudem mógł podołać zapotrzebowaniu miasta na gaz. Dlatego też, od połowy lat dziewięćdziesiątych XIX w. myślano poważnie o kolejnej rozbudowie piecowni retortowej, aby zwiększyć możliwości wytwórcze zakładu oraz o budowie nowego zbiornika mokrego gazu, w celu powiększenia kubatury magazynującej wytwarzany gaz. W sprawie budowy tego ostatniego decyzje zapadły jeszcze w lipcu 1898 r., kiedy radni przychylili się do wniosku o ustawienie nowego zbiornika mokrego o pojemności $15000 \mathrm{~m}^{3}$, które to zadanie zlecono specjalizującej się w tego typu konstrukcjach firmie Augusta Klönne z Dortmundu. W 1899 r., przed nadejściem zimy, poznańska gazownia dysponowała już czwartym, nowym zbiornikiem gazu. Natomiast odnośnie modernizacji i rozbudowy piecowni postanowiono się wstrzymać, mając na względzie fakt, iż w dużych gazowniach europejskich coraz śmielej eksperymentowano z wytwórczością gazu wodnego nawęglanego. Technologia jego produkcji była jednak na tyle nowatorska, że rajcy zdecydowali się wysłać ówczesnego dyrektora gazowni i wodociągów, Hansa Mertensa (1855-19??), w podróż służbową m.in. do Kopenhagi, Londynu i Wiednia, w celu zbadania zasad funkcjonowania oraz zalet instalacji produkcji gazu wodnego,

13 Bericht über die Verwaltung und den Stand der Gemeinde-Angelegenheiten in der Stadt Posen für das Verwaltungsjahr vom 1. April 1898 bis 31. März 1899, Posen 1899, s. 214-215. 
tudzież zapoznania się z różnymi nowinkami technicznymi w gazownictwie ${ }^{14}$. Identyczne zadania otrzymali też członkowie specjalnej komisji samorządowej, ale ci zwiedzali tylko gazownie niemieckie, m.in. w Bremie, Fürstenwalde i Królewcu. Efekty podróży służbowych okazały się jednoznaczne, wszyscy członkowie komisji oraz dyrektor Mertens opowiedzieli się za budową zakładu produkcji gazu wodnego. Jego zalet upatrywano w niewielkich rozmiarach, możliwości zużycia wytwarzanego we własnych piecach retortowych koksu, a przede wszystkim w łatwości - trwającego ledwie kilka godzin - rozruchu i wygaszania gazogeneratorów gazu wodnego. Było to szczególnie pożądane przy nagłych, z reguły krótkotrwałych tylko wzrostach zapotrzebowania na gaz. A te można było wyrównać bardzo łatwo i szybko właśnie dodatkiem potrzebnej ilości gazu wodnego do produkowanego w ruchu ciągłym gazu węglowego. Za optymalny dla poznańskiej gazowni system gazogeneratorów uznano ten opracowany przez londyńską firmę Humphreys \& Glasgow, funkcjonujący już od lat sprawnie i bezawaryjnie w licznych gazowniach angielskich, amerykańskich, duńskich czy belgijskich. Instalacja miała mieć wydajność $500 \mathrm{~m}^{3} / \mathrm{h}$, ale budynek mieszczący urządzenia i cały układ technologiczny zaprojektowano już w takiej skali, aby w jego wnętrzu w późniejszym czasie bez problemów można było ustawić drugi komplet urządzeń o podobnej wydajności ${ }^{15}$.

W czerwcu 1899 r. zgromadzenie radnych podjęło decyzję o przyznaniu 375000 marek na wzniesienie budynku mieszczącego urządzenia technologiczne do produkcji gazu wodnego nawęglanego. Urządzenia dostarczył i zamontował inny z potentatów na niemieckim rynku usług gazowniczych, czyli firma Julius Pintsch A.-G. z Berlina. W końcu stycznia 1900 r. nowoczesna instalacja wytwarzania gazu wodnego, mającego wspomagać zasadniczą produkcję gazu węglowego w godzinach szczytu, była już gotowa do ruchu ${ }^{16}$. Jak się jednak wnet okazało, urządzenia o dobowej zdolności produkcyjnej $12500 \mathrm{~m}^{3}$ nie były w stanie sprostać narastającemu gwałtownie apetytowi Poznania na gaz, zwłaszcza po wcieleniu w 1900 r. w granice miasta dawnych gmin wiejskich: Jerzyce, Św. Łazarz i Wilda, pozbawionych do tej pory dobrodziejstwa w postaci gazu. Na skutki tej inkorporacji, w komunalnej gazowni nad Wartą, nie trzeba było długo czekać. Już bowiem w latach 1900-1901 w starej piecowni zlikwidowano część przestarzałych pieców poziomoretortowych i zastąpiono je pięcioma nowoczesnymi piecami skośnoretortowymi systemu Coze. Ich przewaga nad jednostkami poziomoretortowymi polegała

14 Hans Mertens, urodził się w 1855 r. w Hanowerze, gdzie ukończył szkołę realną, a później też wyższą szkołę techniczną oraz politechnikę. Praktykował ślusarstwo, a następnie był palaczem i maszynistą na Hanowerskich Kolejach Państwowych. Od 1878 r. pracował w należącej do Imperialnego Kontynentalnego Towarzystwa Gazowego gazowni hanowerskiej, następnie od 1879 do 1882 r. był zatrudniony w zakładach Juliusa Pintscha w Berlinie. Kolejne dwa lata, od 1882 do 1884 pracował w miejskich wodociągach i gazowni w Budziszynie, gdzie zapoznał się szczegółowo także z technologią wodociągową. Kolejne trzy lata był już kierownikiem gazowni w Dahlen, zaś od 1888 r. objął posadę pierwszego inżyniera miejskiego, odpowiedzialnego za nadzór nad gazownią i wodociągami w Poznaniu; od 1898 do 1919 r. był dyrektorem Miejskiej Gazowni i Wodociągów w Poznaniu, Archiwum Państwowe w Poznaniu [APP], Akta miasta Poznania, sygn. 2782, życiorys H. Mertensa, k. 1-8.

15 Bericht über die Verwaltung und den Stand der Gemeinde-Angelegenheiten in der Stadt Posen für das Verwaltungsjahr vom 1. April 1898 bis 31. März 1899, s. 213; "Journal für Gasbeleuchtung und Wasserversorgung” r. 42, 1899, nr 25, s. 419; H. Mertens, Über die Licht- und Wasserwerke der Stadt Posen, „Journal für Gasbeleuchtung und Wasserversorgung" r. 47, 1904, nr 36, s. 824-825.

16 Bericht über die Verwaltung und den Stand der Gemeinde-Angelegenheiten in der Stadt Posen für das Verwaltungsjahr vom 1. April 1899 bis 31. März 1900, Posen 1900, s. 240; H. Mertens, op. cit., s. 823-825; Gasanstalten. Julius Pintsch Aktiengesellschaft, Berlin 1915, s. 357-358. 
przede wszystkim na tym, że koks wyrzucany przez piecowych specjalnymi hakami z retort w układzie poziomym, w piecach skośnoretortowych wysypywał się samoczynnie po otwarciu zasuwy retorty. Miało to z jednej strony znaczenie ekonomiczne, gdyż pozwalało ograniczyć personel obsługi, z drugiej zaś zdrowotne dla pracowników, albowiem usuwanie rozżarzonego koksu z pieców i powstające przy tym opary były niesłychanie szkodliwe dla zdrowia. Warunki zdrowotne poprawiono dodatkowo dzięki montażowi specjalnego kanału z wodą do gaszenia i transportu taśmowego gaszonego koksu, czyli tzw. rynny Brouvera, a także instalacji samoczynnego nawęglania retort u góry. Jak widać, dzięki inwestycjom z 1901 r. udało się z jednej strony zmechanizować istotnie ruch piecowni, a z drugiej ograniczyć częściowo obsługę, czyli narażonych najbardziej na trujące wyziewy podczas gaszenia koksu pracowników piecowych. Zdolność produkcyjna gazowni poznańskiej sięgnęła tym samym 30000 m³/dobę, choć jak się znów szybko okazało, już na przełomie 1901 i 1902 r. była zbyt niska ${ }^{17}$.

W związku z odnotowywanymi w grudniu 1901 r. sytuacjami przeciążania pieców, w następnym roku władze samorządowe Poznania zdecydowały o kolejnej rozbudowie swojego zakładu. Zatwierdzony w 1902 r. pakiet inwestycyjny, oszacowany na 326000 marek, zakładał powstanie względnie rozbudowę następujących elementów oraz instalacji technologicznych gazowni: budowę nowej, analogicznej do poprzedniej, baterii pięciu pieców skośnoretortowych wraz z rynną systemu Brouver oraz instalacją samoczynnego nawęglania retort u góry, gruntowną rozbudowę zakładu produkcji gazu wodnego nawęglanego, montaż nowego ssaka gazu i rozbudowę przemysłowej elektrowni do produkcji energii elektrycznej na potrzeby coraz szerzej elektryfikowanego i mechanizowanego ruchu. Wszystkie te inwestycje przeprowadzono w latach 1902-1903. Nowe piece skośnoretortowe systemu Coze, każdy po 9 retort, zbudowały zakłady Augusta Klönne z Dortmundu, zaś rozbudowę instalacji gazu wodnego przeprowadziła spółka akcyjna Juliusa Pintscha z Berlina. W kontekście tego ostatniego wskazać trzeba, że uruchomiony po raz pierwszy w 1900 r. układ technologiczny produkcji gazu wodnego okazał się bardzo ekonomiczny i wydajny, wobec czego teraz rozbudowano go o komplet urządzeń wytwórczych z jeszcze większą wydajnością - $20000 \mathrm{~m}^{3} /$ dobę, uzyskując tym samym łączną zdolność produkcyjną $32500 \mathrm{~m}^{3}$ w ciągu doby. Całość urządzeń technologicznych ustawiono w budynku zakładu gazu wodnego sprzed kilku lat. Modernizację i przebudowę zakładowej elektrowni wykonała Fabryka Silników Gazowych Deutz z Kolonii, a realizacja wszystkich tych przedsięwzięć pozwoliła na wzrost dobowej zdolności produkcyjnej poznańskiej gazowni aż do ok. $72000 \mathrm{~m}^{3}$ gazu węglowego i wodnego łącznie ${ }^{18}$.

W czasie kiedy w Poznaniu przeprowadzono dwie następujące po sobie rozbudowy i modernizacje gazowni (w latach 1900-1901 i 1902-1903), podnosząc zdolność produk-

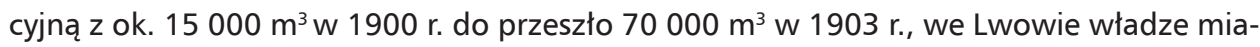
sta dopiero zapoznawały się z niuansami eksploatacji gazowni pod własnym zarządem. Do tego zarządu, w drodze konkursu, na stanowisko dyrektora skomunalizowanej gazow-

17 M. Urbaniak, op. cit., s. 366.

18 Bericht über die Verwaltung und den Stand der Gemeinde-Angelegenheiten in der Stadt Posen für das Verwaltungsjahr vom 1. April 1901 bis 31. März 1902, Posen 1902, s. 248-252; Bericht über die Verwaltung und den Stand der Gemeinde-Angelegenheiten in der Stadt Posen für das Verwaltungsjahr vom 1. April 1902 bis 31. März 1903, Posen 1903, s. 209. 
ni wybrano świetnego fachowca i chemika, dotychczasowego dyrektora gazowni w Stanisławowie, inż. Adama Teodorowicza (1863-1921)19. Ten bardzo szybko zorientował się, że infrastruktura gazowa Lwowa wymaga natychmiastowych i kompleksowych inwestycji, przynajmniej w zakresie sieci gazowej, która - ze względu na niewielkie przekroje - ulegała często zaślepieniu naftaliną i smołą pogazową, a nade wszystko utrudniała utrzymanie właściwego ciśnienia gazu w całym mieście. Niewielkim pocieszeniem mógł być fakt, że urządzenia technologiczne do produkcji w zakładzie posiadały dobową wydajność ok. $10000 \mathrm{~m}^{3}$, co - przynajmniej w pierwszych latach miejskiego zarządu - pozwalało sprostać zapotrzebowaniu grodu nad Pełtwią na gaz. Niemniej jednak, przeprowadzana sukcesywnie już od 1899 r. rozbudowa sieci gazowej szybko i skutecznie poprawiła warunki ciśnieniowe panujące w sieci, przyczyniając się do ułatwienia dystrybucji, co - w połączeniu z obniżką cen gazu dla odbiorców prywatnych - poskutkowało gwałtownym wzrostem jego konsumpcji, dochodzącej w 1904 r. już do 3,5 mln $\mathrm{m}^{3} \mathrm{gazu}^{20}$.

Aby podołać rosnącemu zapotrzebowaniu na gaz, już w 1900 r. w piecowni zamontowano kilka nowych pieców 8-retortowych w układzie poziomym, a równocześnie część starych bloków piecowych o 6 retortach przebudowano także na jednostki 8-retortowe. Zmodernizowano i powiększono również instalacje do czyszczenia gazu, dzięki czemu wytwórczość zakładu wzrosła do 15 000-16 $000 \mathrm{~m}^{3}$ na dobę ${ }^{21}$. Efekt był taki, że o kilka lat udało się jeszcze odsunąć poważniejszą rozbudowę przedsiębiorstwa, ale gdy w 1904 r. wyprodukowano w nim 3,5 $\mathrm{mln} \mathrm{m}^{3}$ gazu, dalsze odwlekanie niezbędnych inwestycji było już niemożliwe. Jak łatwo się domyślić, aby podnieść zdolność produkcyjną całego ciągu technologicznego, trzeba było zacząć od jego pierwszego i najważniejszego ogniwa, czyli piecowni i urządzeń służących do generowania gazu. Inż. Teodorowicz zastanawiał się wprawdzie nad wprowadzeniem do gazowni lwowskiej także pieców skośnoretortowych systemu Coze, analogicznie do Poznania, ale ostatecznie doszedł do wniosku, że stanowią one konstrukcję przejściową, i zamiast pieców retortowych, korzystniej będzie zbudować i uruchomić instalację gazogeneratorów do produkcji gazu wodnego nawęglanego. Ku takiemu rozwiązaniu skłoniły go m.in. brak miejsca pod znaczącą rozbudowę piecowni i pod nowe magazyny węgla na terenie istniejącego zakładu, a ponadto chęć zużytkowania taniejącego coraz mocniej koksu, wytwarzanego masowo w procesie suchej destylacji węgla w piecach retortowych. Do tego dochodziła jeszcze możność wykorzystywania - w procesie karburyzacji (nawęglania) gazu wodnego - dostępnych lokalnie olejów naftowych, a tym samym niższe koszty produkcji takiego gazu. Zapewne nie bez znaczenia były też doświadczenia i wiedza zdobyte przez Teodorowicza podczas podróży służbowych, w trakcie których zapoznał się z nowoczesnymi gazowniami pracującymi przy użyciu pieców retortowych oraz instalacji technologicznych do wytwarzania gazu wodnego nawęglanego ${ }^{22}$.

W konsekwencji, na początku 1905 r. zaproponował on program rozbudowy, zakładający powstanie na terenie gazowni instalacji produkcji gazu wodnego o dobowej wydajności rzędu $15000 \mathrm{~m}^{3}$, czyli uzyskanie całkowitej zdolności produkcyjnej lwowskiej ga-

19 [?], Ś.P. Inż. Adam Teodorowicz, „Przegląd Gazowniczy” r. 1, 1921, nr 1, s. 1-2.

20 A. Teodorowicz, O rozwoju gazowni, nr 1, s. 6-7.

21 Sprawozdanie Komisji Gazowej z administracji gazowni za czas od 1. stycznia do 31. grudnia 1900, Lwów 1901 , s. 3-7.

22 A. Teodorowicz, o rozwoju gazowni, nr 1, s. 7-8. 


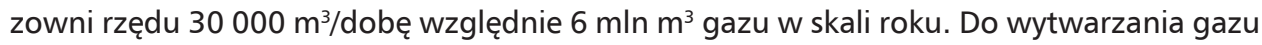
wodnego nawęglanego przewidział dwa komplety gazogeneratorów, każdy o wydajności ok. $780 \mathrm{~m}^{3} / \mathrm{h}$, ponadto zaplanował powstanie nowoczesnej aparatowni z odsiarczalnią o wydajności $30000 \mathrm{~m}^{3} /$ dobę, budowę nowej kotłowni parowej oraz kolejnego zbiornika mokrego gazu, tym razem o pojemności 10000 m³. Całość miała kosztować 679750 koron, a wraz z jednoczesną rozbudową sieci gazowej oraz montażem kolejnych 950 latarni ulicznych oszacowana została łącznie na $1 \mathrm{mln}$ koron ${ }^{23}$.

Analogicznie do Poznania, we Lwowie wybrano również system gazogeneratorów patentu Humphreys \& Glasgow, a jego dostawę i montaż powierzono specjalizującej się w tego typu instalacjach firmie Julius Pintsch A.-G. z Berlina, lecz z filią w Wiedniu. Całość instalacji została zamontowana w 1906 r. w nowo powstałym budynku, a w końcu roku oddana do ruchu. Z kolei wykonanie wyposażenia aparatowni i odsiarczalni, a później jego montaż, zlecono znanej i cenionej w całej Europie firmie Berlińsko-Anhalcka Fabryka Budowy Maszyn S.A. (Berlin-Anhaltische Maschinenbau A.-G. - BAMAG) z Berlina. Notabene warto może odnotować, że lwowski zakład gazu wodnego powstał krótko po identycznej instalacji firmy Pintscha dla Wiednia, gdzie w 1904 r. uruchomiono gazogeneratory gazu wodnego nawęglanego o wytwórczości 100000 m³/dobę 24 .

Wydawać by się mogło, że podniesienie zdolności produkcyjnej gazowni do $6 \mathrm{mln} \mathrm{\textrm {m } ^ { 3 }}$ rocznie pozwoli na dłuższy czas zabezpieczyć apetyt Lwowa na gaz. Tymczasem kalkulacje te okazały się całkiem płonne, gdyż już w 1910 r. zanotowano oddanie gazu do sieci w wysokości niemal 6,15 mln $\mathrm{m}^{3}$, a zatem właściwa produkcja była jeszcze większa i możliwa do osiągnięcia tylko dzięki forsowaniu uruchomionej w 1906 r. instalacji produkcji gazu wodnego. Notabene zalety posiadania gazogeneratorów gazu wodnego władze Lwowa odczuły poważnie już w lecie 1908 r., kiedy podczas strajku robotników w gazowni, zabezpieczenie dostaw gazu dla miasta okazało się możliwe tylko dzięki pracy wspomnianej instalacji i 50-procentowej domieszce gazu wodnego do świetlnego ${ }^{25}$. Abstrahując od tej nadzwyczajnej sytuacji, w 1910 r. stało się jasne, że zmodernizowana i rozbudowana kilka lat wcześniej gazownia wymaga znów poważnej rekonstrukcji względnie zwiększenia dobowej zdolności produkcyjnej.

Tymczasem stary zakład gazowniczy przy ul. Gazowej lub ul. Źródlanej, ze względu na lokalizację w gęsto zabudowanym centrum miasta, posiadał jedynie ograniczone możliwości rozwoju przestrzennego, a zatem i rozbudowy. Dlatego też już w 1907 r. samorząd municypalny nabył po korzystnej cenie dużą parcelę na przedmieściach, w sąsiedztwie miejskiej rzeźni przy trakcie Żółkiewskim. Teren był skomunikowany bocznicą kolejową, a do tego tak rozległy, iż z łatwością można było projektować na nim budowę od podstaw nowoczesnego zakładu gazowniczego o rocznej zdolności produkcyjnej rzędu $50 \mathrm{mln} \mathrm{m}^{3}$. Tymczasem władze samorządowe zdecydowały się jednak na kolejne inwestycje w dotychczasową gazownię, na terenie której w latach 1911-1912 rozbudowano

23 Ibid.

24 DALO, fond 3, opis 1, spr. 4980, wniosek Komisji Gazowej z 28 VI 1905; fond 3, op. 1, spr. 5104, pisma Dyrekcji Miejskiego Zakładu Gazowego o wypłatę zaliczek za wykonane prace z 23 III i 12 VII 1906; fond 599, op. 1, spr. 6, opis projektowanych urządzeń w gazowni miejskiej we Lwowie z 1905 r.; Gasanstalten. Julius Pintsch, s. 359.

25 „Journal für Gasbeleuchtung und Wasserversorgung” r. 52, 1909, nr 8, s. 165; A. Teodorowicz, O rozwoju gazowni, nr 1, s. 8. 
znów piecownię, montując w jej wnętrzu trzy nowe jednostki 9-retortowe, zaopatrzone w generatory do ogrzewania retort. Ponadto wprowadzono mechaniczny system załadunku retort oraz ich opróżniania z koksu i przesyłania taśmociągiem transportującym bezpośrednio do rynny z wodą (system Brouver), a zatem rozwiązania znane z Poznania, choć spóźnione o dekadę względem stolicy prowincji poznańskiej. Powiększono też układ technologiczny aparatowni do dobowej wytwórczości rzędu 25000 m³/dobę, a jednocześnie - właśnie w 1912 r. - zdecydowano się wysłać dyrektora Teodorowicza w podróż studyjną po gazowniach niemieckich, szwajcarskich, francuskich i angielskich, w celu zgromadzenia wiedzy oraz zapoznania się z najnowszymi rozwiązaniami technicznymi w gazownictwie europejskim²6.

W czasie kiedy inż. Teodorowicz podróżował po Europie i zapoznawał się naocznie z postępem technicznym w gazownictwie, równorzędny mu stanowiskiem inż. Mertens w Poznaniu był dosłownie w przededniu podobnych podróży, albowiem podległy mu zakład w 1910 r. przekazał do sieci 11,3 $\mathrm{mln} \mathrm{m}^{3}$, a w ostatnim roku pokoju - 1913 - aż 13,9 $\mathrm{mln} \mathrm{m}^{3}$ gazu, stając również u kresu swych możliwości produkcyjnych ${ }^{27}$. Opracowana w 1913 r. koncepcja techniczna rozbudowy i modernizacji poznańskiej gazowni została pozytywnie zaopiniowana przez administrację komunalną w marcu 1914 r., ale aby upewnić się o słuszności przyjętych założeń i planowanych rozwiązań technicznych, wysłano równocześnie Mertensa z kilkoma samorządowcami w delegację służbową do różnych dużych gazowni europejskich. Po powrocie cała delegacja orzekła, że przygotowany projekt kompleksowej rozbudowy zakładu jest optymalny dla stolicy Wielkiego Księstwa Poznańskiego. W ramach inwestycji zamierzano m.in. zbudować nową piecownię wraz z silosem na węgiel (ok. 2,1 mln marek), wprowadzić komunikację szynową na terenie zakładu i wykonać doń bocznicę wraz z mostem kolejowym, celem łatwego dowozu węgla do gazowni (ok. 0,2 mln marek), zbudować estakady kolei wiszącej wraz z żurawiami elektrycznymi do transportu węgla i koksu na terenie zakładu (ok. 0,6 mln marek), zmodernizować aparatownię i jej urządzenia techniczne (ok. 0,4 mln marek) i wreszcie ustawić nowy zbiornik gazu, oszacowany również na ok. 0,4 mln marek. Całkowity koszt inwestycji, łącznie z pracami oraz dodatkowymi obiektami miał sięgnąć aż 4,5 mln marek, a dobowa zdolność produkcyjna zakładu powinna była wzrosnąć do ok. 120 000/140 $000 \mathrm{~m}^{3}$ gazu$^{28}$.

Kluczowymi elementami nowego założenia były piecownia oraz zbiornik gazu. W wypadku tej pierwszej zdecydowano się na nowatorską pod względem technicznym konstrukcję piecowni poziomokomorowej w układzie sprzężonym z centralną stacją gazogeneratorów do produkcji - służącego do opalania komór - gazu generatorowego. Wprawdzie tego typu piecownie spotykane były w dużych koksowniach, ale w miejskich gazowniach były całkowitym ewenementem. W 1914 r. w Niemczech piecownia taka działała tylko w Królewcu, a druga była właśnie w budowie na terenie gazowni w Lichtenbergu pod Berlinem. Jej zaletą była możliwość opalania komór zarówno gazem generatorowym, jak i gazem świetlnym, produkowanym w tradycyjnych piecach retortowych. Było to o tyle istotne, że

26 A. Teodorowicz, O rozwoju gazowni, nr 1, s. 8.

27 Bericht über die Verwaltung der Residenzstadt Posen für die Zeit vom 1. April 1910 bis 31. März 1911, Posen [1911], s. 158; Bericht über die Verwaltung der Residenzstadt Posen für die Zeit vom 1. April 1913 bis 31. März 1914, Posen [1914], s. 182.

28 Bericht über die Verwaltung der Residenzstadt Posen für die Zeit vom 1. April 1914 bis 31. März 1915, Posen [1915], s. 218-231. 
pozwalało doskonale zrównoważyć ruch gazowni w skali całego roku. W lecie bowiem, kiedy zapotrzebowanie na gaz malało, a zatem spadała też i produkcja koksu, do opalania komór nowej piecowni można było wykorzystać gaz węglowy wytwarzany w starej piecowni, zwiększając tym samym jego zużycie i produkcję droższego w tym czasie koksu. W zimie natomiast, kiedy zapotrzebowanie na gaz gwałtownie rosło, a zatem zwiększały się i rezerwy taniejącego szybko koksu, ten ostatni można było wykorzystać do produkcji gazu generatorowego i tym samym przejść na opalanie komór gazem wytwarzanym przez centralną stację gazogeneratorów nowej piecowni. Na wykonawcę awangardowego obiektu wybrano słynną firmę Heinrich Koppers z Essen, a właściwa piecownia została uzupełniona jeszcze o żelbetowe silosy węgla o pojemności 22000 t, ulokowane nad układem komór, co gwarantowało rezerwę ruchową na ok. 40 dni pracy. Natomiast wspomniany zbiornik gazu, mający gromadzić $50000 \mathrm{~m}^{3}$, zyskał również - ze względu na dużą wielkość - rzadko spotykaną konstrukcję, stając się patentowanym zbiornikiem suchym względnie bezwodnym. Jego dostawcą została firma Augusta Klönne z Dortmundu. Pozostałe elementy oraz urządzenia techniczne, przewidziane do wprowadzenia podczas modernizacji, miały z jednej strony umożliwić proces oczyszczania istotnie zwiększonej ilości wytwarzanego gazu surowego, a z drugiej wprowadzić maksymalną mechanizację ruchu, zwalniając w miarę możliwości ludzi z najbardziej niezdrowych i uciążliwych prac. Było to poniekąd zresztą konieczne, gdyż podniesienie wytwórczości gazowni poznańskiej do ok. $120000 \mathrm{~m}^{3}$ na dobę oznaczało de facto jej przekształcenie w olbrzymi i nowoczesny zakład przemysłowy ${ }^{29}$.

Tymczasem zbliżała się I wojna światowa, a jej wybuch w lipcu 1914 r. spowodował, że wniosek magistratu do rady miejskiej o uchwalenie środków finansowych na rozbudowę gazowni został cofnięty. Szybko okazało się jednak, że kilkumilionowej inwestycji nie da się uniknąć względnie przeczekać do końca światowego konfliktu. Zużycie gazu, pomimo wojennej zawieruchy wzrastało, a przyczyniały się do tego m.in. narastający deficyt używanej jeszcze dość powszechnie do oświetlenia nafty oraz podstawowego materiału opałowego, czyli węgla. Efekt był taki, że choć z każdym następnym rokiem wojny sytuacja gospodarczo-ekonomiczna ludności Poznania ulegała pogorszeniu, to jednak zużycie gazu - aż do końca 1917 r. - szybko rosło. Ostatecznie, w pierwszej połowie 1915 r. zgromadzenie radnych musiało zatwierdzić środki na okrojony program rozbudowy zakładu, dzięki czemu już w marcu tegoż roku przystąpiono do kilkuletniej inwestycji. Brak fachowców zmobilizowanych na front, kłopoty z transportem kolejowym oraz zapewnieniem potrzebnych materiałów budowlanych spowodowały, że prace ciągnęły się aż do lat 1916-1917. Wtedy to do eksploatacji oddano m.in. nowatorską piecownię sprzężoną poziomokomorową systemu Koppers oraz zbiornik suchy gazu o największej w Poznańskiem pojemności $50000 \mathrm{~m}^{3}$. Przy okazji tych inwestycji udało się też zmechanizować w wyższym stopniu prowadzenie ruchu zakładu, choć olbrzymie ułatwienie - w postaci doprowadzenia bocznicy z mostem kolejowym nad Wartą do zakładu - udało się osiągnąć dopiero w grudniu 1918 r. Notabene inwestycja ta była wręcz konieczna, gdyż dowóz węgla wozami konnymi ze stacji do gazowni był niezwykle trudny, skomplikowany i wiązał się z narastającym szybko zjawiskiem kradzieży węgla ${ }^{30}$.

29 M. Urbaniak, op. cit., s. 372-376.

30 Ibid., s. 377; Sprawozdanie z działalności Zarządu Miejskiego St. M. Poznania za lata 1918-1920, Poznań 1921, s. 108 . 


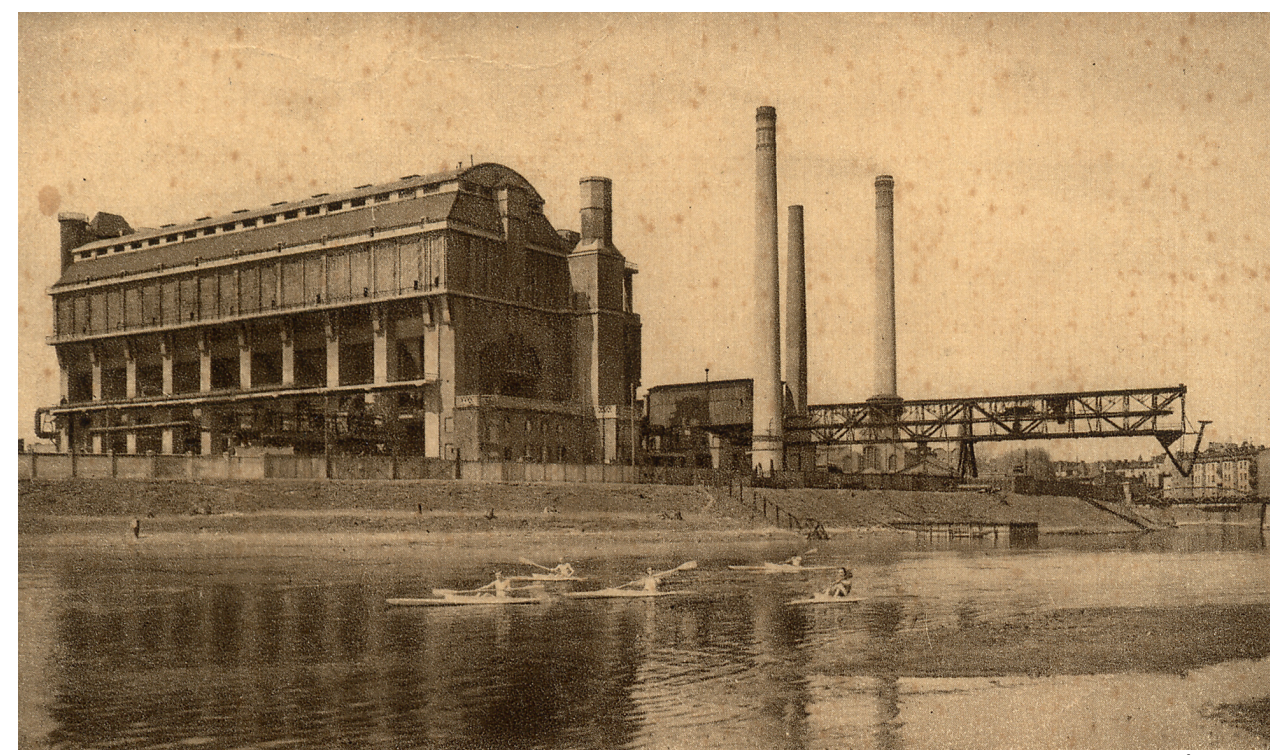

Piecownia poziomokomorowa systemu Koppers w Poznaniu w okresie międzywojennym (Źródło: M. Urbaniak).

Jak wspomniałem już wcześniej, Iwowski dyrektor gazowni inż. Teodorowicz swą podróż studyjną po europejskich gazowniach odbył już w 1912 r., ale - paradoksalnie - losy koncepcji modernizacji i rozbudowy jego gazowni okazały się w dużym stopniu zbieżne z losami omawianej inwestycji w Poznaniu. Tak oto, po powrocie z europejskiej delegacji służbowej Teodorowicz przystąpił do opracowywania koncepcji i projektu rozbudowy swojej gazowni, który to projekt ukończył w następnym roku, przedkładając go władzom samorządowym stolicy Galicji i Lodomerii. Dyrektor zakładał budowę - na terenie starego zakładu gazowniczego w centrum miasta - nowej piecowni oraz aparatowni i odsiarczalni do oczyszczania surowego gazu, wszystko to o dobowej zdolności produkcyjnej $50000 \mathrm{~m}^{3}$. Równocześnie zaproponował, aby na gruntach przewidzianych pod realizację nowej gazowni, przy Trakcie Żółkiewskim, urządzić składnicę węgla wraz z budynkami magazynowymi. Odstawiany tam przy pomocy bocznicy kolejowej węgiel, miał być transportowany na bieżąco do starej gazowni za pomocą dwóch aut ciężarowych. Faktem jest, że rozwiązanie to praktykowano tylko do czasu I wojny światowej, gdyż w jej trakcie obie ciężarówki zarekwirowało wojsko, ale wówczas wprowadzono system transportu węgla za pomocą wagonów ciągniętych po szynach tramwajowych $^{31}$.

W ramach projektowanej rozbudowy, Teodorowicz przewidział początkowo montaż wyposażenia aparatowni o zdolności produkcyjnej $25000 \mathrm{~m}^{3} /$ dobę, a dopiero w kolejnym etapie jego rozbudowę do wydajności $50000 \mathrm{~m}^{3}$. Natomiast wyposażenie technologiczne odsiarczalni (skrzynie odsiarczalne) miały posiadać od początku wydajność rzędu $50000 \mathrm{~m}^{3}$. Równocześnie, aby zapewnić odpowiednią kubaturę do magazynowania 
wytwarzanego gazu, dyrektor Teodorowicz założył budowę czwartego zbiornika gazu, o pojemności $30000 \mathrm{~m}^{3}$, który w późniejszym czasie zamierzano ustawić na gruntach nowej gazowni przy Trakcie Żółkiewskim, a gaz węglowy przetłaczać do niego ze starego zakładu za pomocą stacji kompresorów. Sama piecownia, przewidziana początkowo do produkcji gazu rzędu $15000 \mathrm{~m}$ 3/dobę, z możliwością jej rozbudowy do wytwórczości $50000 \mathrm{~m}^{3} /$ dobę, miała powstać na terenie starej gazowni. Jako optymalną konstrukcję wybrano piec pionoworetortowy systemu Glover West, przyjmując jako jego zalety równoczesną możliwość produkcji gazu wodnego, a także większą wydajność gazu przy jednocześnie mniejszym zużyciu węgla do opalania retort i mniejszych kosztach personelu obsługi. Nie bez znaczenia był też fakt, iż proces ładowania retort pieców systemu Glover West następował w zamkniętej u góry przestrzeni, a zatem nie generował pyłów i kurzu, podobnie jak i usuwanie z retort koksu, który w tego typu piecach był już całkowicie wygaszony, eliminując dzięki temu konieczność jego uciążliwego gaszenia, połączonego z emisją trujących wyziewów i oparów. W warunkach starego zakładu gazowniczego, funkcjonującego w gęsto zabudowanym centrum miasta, a zatem oznaczającego uciążliwości dla otoczenia, były to zalety trudne do przecenienia ${ }^{32}$.

Planując budowę w gazowni Iwowskiej piecowni systemu Glover West, dyrektor Teodorowicz miał jednak poważne rozterki odnośnie prowadzenia ruchu pieców pionoworetortowych, do których zamierzano wykorzystywać węgiel z kopalń w Zagłębiu Ostrawsko-Karwińskim oraz austro-węgierskiej części Górnego śląska. Aby je rozwiać, zwrócił się z prośbą o przeprowadzenie doświadczeń z tego typu węglem na piecowni systemu Glover West, pracującej w największej gazowni Berlina w Mariendorf, będącej własnością londyńskiego Królewskiego Kontynentalnego Towarzystwa Gazowego (Imperial Continental Gas Association). Próby wypadły bardzo pomyślnie, wobec czego 1 sierpnia 1913 r. zgromadzenie radnych miejskich przyznało środki finansowe na realizację inwestycji, którą wkrótce podjęto. Wraz z wybuchem I wojny światowej i okupacją Lwowa od września 1914 r. do czerwca 1915 r. przez Rosjan, prace jednak całkowicie wstrzymano, wznawiając je dopiero w 1916 r. Budowę nowoczesnej piecowni pionoworetortowej systemu Glover West zlecono renomowanej Szczecińskiej Fabryce Szamotu S.A., dawniej Didier (Stettiner Chamottefabrik Aktien-Gesselschaft, vormals Didier), będącej monopolistą w wykonywaniu pieców tego systemu na kontynencie europejskim. Okazało się jednak, że w trakcie światowego konfliktu nie była ona w stanie budować pieców tej konstrukcji i w efekcie zamiast piecowni Glover West, zrealizowano ostatecznie piecownię z piecami pionoworetortowymi, lecz systemu dessauskiego. Obiekt o dobowej zdolności produkcyjnej $15000 \mathrm{~m}^{3}$ gazu zbudowano w 1917 r., ale całość inwestycji kończono jeszcze w następnych latach, już po I wojnie światowej. Notabene w trakcie wojny kolejny raz okazało się, jak dalekowzrocznym i praktycznym rozwiązaniem była swego czasu budowa zakładu gazu wodnego nawęglanego. Dzięki gazogeneratorom gazu wodnego problemy z regularnymi dostawami węgla, a niekiedy nawet jego brak, rekompensowano bez trudu zwiększoną produkcją gazu wodnego, mieszanego z gazem węglowym niekiedy w stosunku nawet 70 do $30 \%{ }^{33}$. vormals Didier. 50 Jahre Aktiengesellschaft 1872-1922, Berlin 1922, s. 128. 
Tabela 1. Podstawowe dane techniczno-produkcyjne gazowni Poznania i Lwowa w latach 19001917

\begin{tabular}{|c|c|c|c|c|c|c|c|c|c|}
\hline & & 1900 & 1905 & 1907 & 1910 & 1913 & 1914 & 1915 & 1917 \\
\hline \multirow{3}{*}{$\mid \begin{array}{l}\frac{1}{0} \\
\frac{1}{N} \\
0 \\
0 \\
0\end{array}$} & $\begin{array}{l}\begin{array}{l}\text { Długość sieci gazowej } \\
(\mathrm{km})\end{array} \\
\end{array}$ & $?$ & 108,9 & 127,1 & 133,0 & 153,5 & 167,2 & 168,9 & 169,3 \\
\hline & $\begin{array}{l}\text { Liczba latarni } \\
\text { publicznych }\end{array}$ & 1543 & 2895 & 3240 & 3456 & 3882 & 3882 & 3882 & 3882 \\
\hline & $\begin{array}{l}\text { Produkcja/oddanie } \\
\text { gazu }\left(\mathrm{mln} \mathrm{m}^{3}\right)\end{array}$ & 5,081 & 8,075 & 10,098 & 11,295 & 13,935 & 12,641 & 14,881 & 16,685 \\
\hline \multirow{3}{*}{ 3. } & $\begin{array}{l}\text { Długość sieci gazowej } \\
(\mathrm{km})\end{array}$ & 55,6 & 85,3 & 123,6 & $?$ & $?$ & $?$ & $?$ & $?$ \\
\hline & $\begin{array}{l}\text { Liczba latarni } \\
\text { publicznych }\end{array}$ & 1669 & 1964 & 2867 & 3541 & $?$ & $?$ & $?$ & $?$ \\
\hline & $\begin{array}{l}\text { Produkcja/oddanie } \\
\text { gazu }\left(\mathrm{mln} \mathrm{m}^{3}\right)\end{array}$ & 2,742 & 3,933 & 4,955 & 6,148 & 7,585 & 7,186 & 5,579 & 7,628 \\
\hline
\end{tabular}

Źródło: Bericht über die Verwaltung und den Stand der Gemeinde-Angelegenheiten in der Stadt Posen für das Verwaltungsjahr vom 1. April 1900 bis Ende März 1901, Posen 1901, s. 282-283; Bericht über die Verwaltung der Provinzial-Hauptstadt Posen für die Zeit vom 1. April 1905 bis 31. März 1906, Posen 1906, s. 170; Bericht über die Verwaltung der Provinzial-Hauptstadt Posen für die Zeit vom 1. April 1907 bis 31. März 1908, Posen 1908, s. 171-173; Bericht über die Verwaltung der Residenzstadt Posen für die Zeit vom 1. April 1910 bis 31. März 1911, Posen 1911, s. 158-159; Bericht über die Verwaltung der Residenzstadt Posen für die Zeit vom 1. April 1913 bis 31. März 1914, Posen [1914], s. 182-183; Bericht über die Verwaltung der Residenzstadt Posen für die Zeit vom 1. April 1915 bis 31. März 1916, Posen [1916], s. 181; Bericht über die Verwaltung der Residenzstadt Posen für die Zeit vom 1. April 1916 bis 31. März 1917, Posen [1917], s. 186; Bericht über die Verwaltung der Residenzstadt Posen für die Zeit vom 1. April 1917 bis 31. März 1918, Posen [1918], s. 183; A. Teodorowicz, O rozwoju gazowni we Lwowie, "Przegląd Gazowiczy" r. 1, 1921, nr 2, s. 28; Sprawozdanie Komisji Budżetowej król. stoł. miasta Lwowa o projekcie budżetu gminy, tudzież funduszów i fundacji w jej zarządzie będących za rok 1902, Lwów 1902, s. 13; Sprawozdanie Komisji Budżetowej król. stot. miasta Lwowa o projekcie budżetu gminy na rok 1904, Lwów 1904, s. 35; Sprawozdanie Komisji Budżetowej król. stoł. miasta Lwowa o budżecie gminy na rok 1906, Lwów 1906, s. 26-27; Sprawozdanie Komisji Budżetowej król. stoł. miasta Lwowa o budżecie gminy na rok 1907, Lwów 1907, s. 25; Sprawozdanie Komisji Budżetowej miasta Lwowa o projekcie budżetu gminy, tudzież funduszów i fundacji w jej zarządzie będących za rok 1908, Lwów 1908, s. 35; J. Konopka, Gazownictwo polskie i jego rozwój w świetle liczb i wykresów, Warszawa 1928, s. 184.

Jak widać, kluczowe rozbudowy i modernizacje obydwie gazownie przeszły już w trakcie I wojny światowej, przy czym o ile poznańska inwestycja doszła do skutku, choć w okrojonym względem początkowej koncepcji rozmiarze, jeszcze do końca zaborów, o tyle Iwowska była finalizowana już w pierwszych latach po odzyskaniu przez Polskę niepodległości. Niemniej jednak gazownia Iwowska zyskała dobową zdolność wytwórczą $55000 \mathrm{~m}^{3}$ (piecownia poziomoretortowa $25000 \mathrm{~m}^{3}$, piecownia pionoworetortowa $15000 \mathrm{~m}^{3}$ i zakład gazu wodnego nawęglanego $15000 \mathrm{~m}^{3}$ ). W stosunku do możliwości wytwórczych gazowni poznańskiej, w wypadku piecowni sięgających ok. 120000 m³ dobę, była to wprawdzie niespełna połowa, ale też i skala produkcji gazu w obu miastach była nieporównywalna. W czasie kiedy we Lwowie w 1917 r. oddano do sieci ok. 7,6 mln m³, w Poznaniu było to rekordowe w trakcie zaborów 16,5 $\mathrm{mln}^{3}$ gazu $^{34}$. Niezależnie jednak 


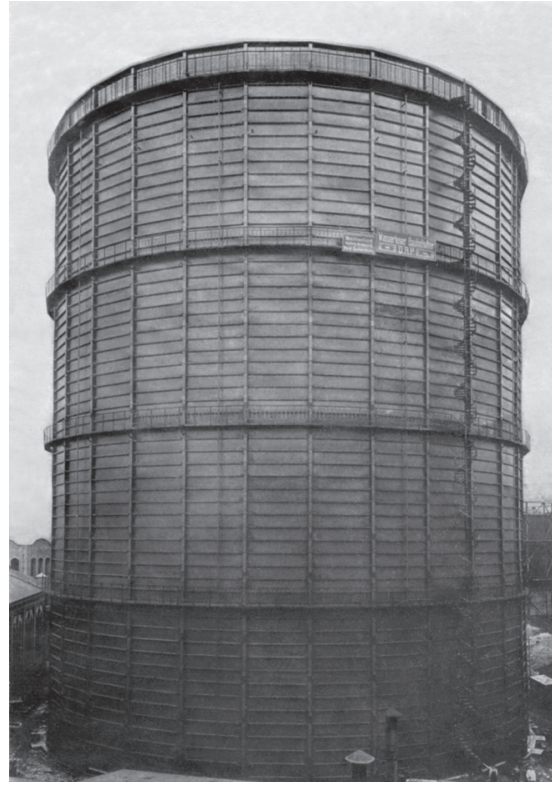

Zbiornik bezwodny o pojemności $50000 \mathrm{~m}^{3}$ gazu w Poznaniu wkrótce po budowie - ok. 1920 r. (Źródło: A. Dziurzyński, 75-lecie Gazowni Miejskiej w Poznaniu, „Gaz i Woda” r. 11, 1931, nr 12). od tego, jak widać z powyższej tabeli, przed I wojną światową obydwa miasta dysponowały już zbliżoną długością sieci gazowej, wynoszącą w 1907 r. w Poznaniu 127 km i niemal 124 km we Lwowie. W tym ostatnim nastąpiła też bardzo widoczna poprawa w sferze oświetlenia publicznego, bowiem o ile jeszcze w 1905 r. działały tu 1964 latarnie uliczne w stosunku do 2895 lamp w Poznaniu, o tyle w 1910 r. było to już odpowiednio 3541 oraz 3456.

Gazownie poznańska i lwowska powstały niemal w identycznym czasie, w latach 50. XIX w., aczkolwiek aż do końca XIX w. funkcjonowały w zgoła odmiennych warunkach gospodarczoekonomicznych. Ta pierwsza od początku była przedsiębiorstwem samorządowym, druga zaś stała się nim dopiero w 1898 r., po przejęciu przez miasto od dotychczasowego właściciela prywatnego. Niezależnie od tego faktu obydwa zakłady przeszły gruntowne modernizacje i rozbudowy niemal w tym samym czasie, na początku XX w. W Poznaniu inwestycje modernizacyjne przeprowadzono dwufazowo w latach 1900-1903, we Lwowie zaś w latach 1905-1906. Przy czym wykazały one ewidentny uniwersalizm postępu technicznego w ówczesnym gazownictwie, a zarazem świetne rozeznanie w innowacjach technologicznych kadr inżynieryjnych obydwu zakładów, reprezentowanych przez dyrektora Hansa Mertensa w Poznaniu i Adama Teodorowicza we Lwowie. Świadectwem tego są przede wszystkim zbudowane w Poznaniu i Lwowie zakłady gazu wodnego nawęglanego, w dodatku według identycznego systemu Humphreys \& Glasgow, tudzież wprowadzenie mechanicznego załadunku retort w piecowniach klasycznych oraz systemu gaszenia koksu w tzw. rynnach systemu Brouvera. Swoją drogą trudno dziś dociec, czy dyrektor Teodorowicz w swych koncepcjach modernizacyjnych nie wzorował się też $\mathrm{m}$.in. na rozwiązaniach technologicznych zastosowanych kilka lat wcześniej właśnie w Poznaniu. Nie da się bowiem ukryć, że podobieństwo wprowadzonych we Lwowie rozwiązań jest uderzające.

Ostatnia dekada przed wybuchem I wojny światowej to w obu miastach czas prosperity ich gazowni, niezakłócony nawet uruchomieniem konkurencyjnych względem gazowni miejskich elektrowni: poznańskiej w 1904 r. i lwowskiej w 1900 r. oraz drugiej i znacznie większej, w 1909 r. ${ }^{35}$ Tym sposobem oddanie gazu w Poznaniu w 1910 r. sięgnęło już $11,3 \mathrm{mln} \mathrm{m}^{3}$, zaś we Lwowie $6,1 \mathrm{mln}^{3}$. W obu ośrodkach był to zarazem sygnał, że ich zakłady gazownicze wymagają kolejnej i gruntownej rozbudowy, połączonej ze wzrostem dobowej zdolności produkcyjnej, w Poznaniu mającej sięgnąć aż 120 000/140 000 m³,

35 H. Maik, W. Daktera, Elektrownie i elektrociepłownie miasta Poznania, [w:] 100 lat poznańskiej energetyki, Poznań 2004, s. 15; J. Tomicki, Ze statystyki Miejskich Zakładów Elektrycznych we Lwowie, Lwów 1912, s. 2-10; A. Krizhanivskij, Istorija elektryfikacji Lvivshchiny, Lviv 2015, s. 42, 57-60. 


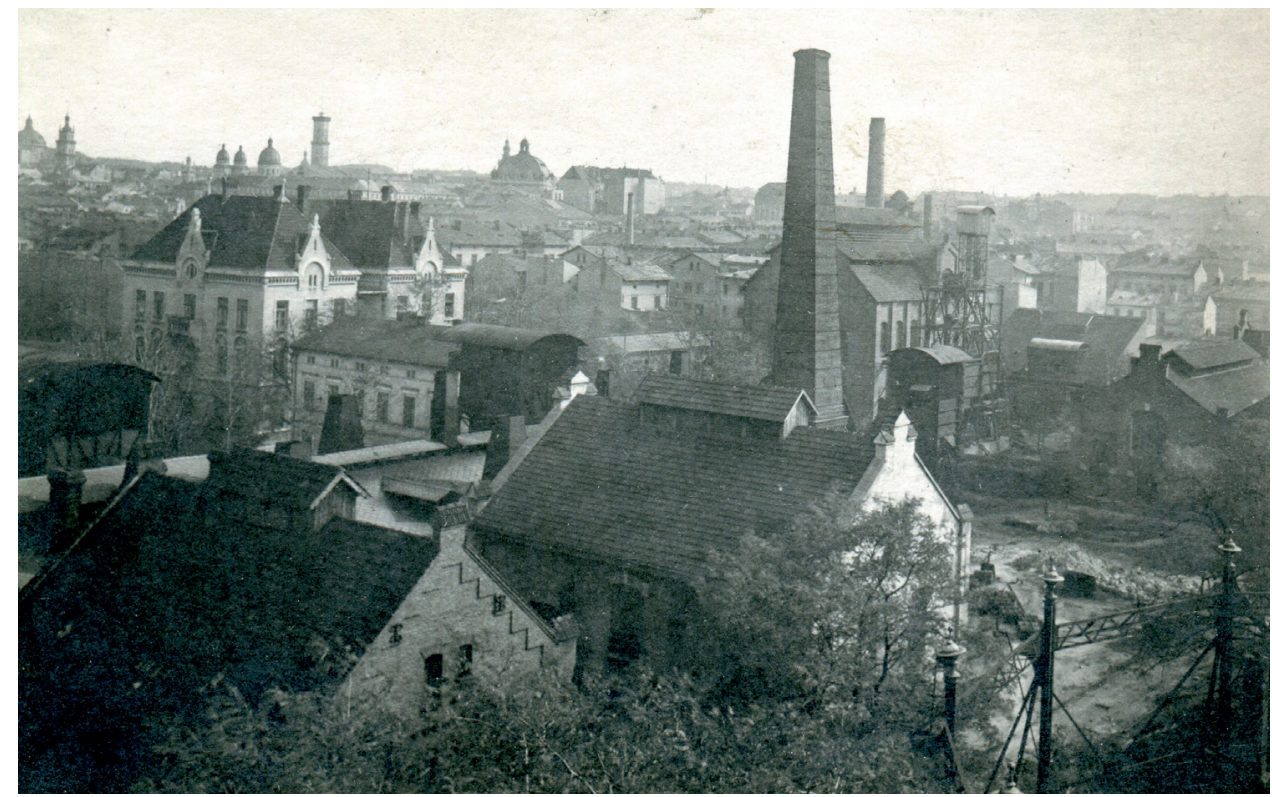

Gazownia lwowska w okresie międzywojennym, z prawej, za kominem widoczna piecownia pionoworetortowa systemu dessauskiego (Źródło: zbiory Igora i Iriny Kotłobułatowych).

a we Lwowie $50000 \mathrm{~m}^{3}$ gazu. W celu urzeczywistnienia założonych celów i nad Wartą, i nad Pełtwią zaplanowano kosztowne rozbudowy, w Poznaniu zmaterializowane w dużym stopniu jeszcze w trakcie I wojny światowej, zaś we Lwowie w jej ostatnich latach i pierwszych latach niepodległej II Rzeczypospolitej. Faktem jest, że inwestycja przeprowadzona w Poznaniu uczyniła z jego gazowni obiekt nowoczesny i awangardowy pod względem technicznym w skali międzywojennej Polski, a przesądziły o tym unikatowa i nowatorska sprzężona piecownia poziomokomorowa systemu Koppers oraz zbiornik suchy (bezwodny) o pojemności $50000 \mathrm{~m}^{3}$, notabene uszkodzony przez wybuch i rozebrany w 1926 r. ${ }^{36}$ Niemniej jednak, we Lwowie w tym samym czasie planowano również budowę dużego zbiornika o pojemności $30000 \mathrm{~m}^{3}$, choć niezmaterializowaną, aczkolwiek wystawiono wyjątkową pod względem technicznym piecownię pionoworetortową systemu dessauskiego, sytuującą gazownię Iwowską - po warszawskiej (1908 r.), chorzowskiej, a wówczas królewskohuckiej (1910 r.) i bydgoskiej (1913 r.) - w gronie jedynie czterech zakładów gazowniczych dysponujących piecownią tego systemu u zarania II Rzeczypospolitej ${ }^{37}$.

Jak widać, choć obydwa miasta dzieliła olbrzymia odległość, dzieliła inna rzeczywistość polityczna, ale też i spora różnica w zaludnieniu, to jednak - z punktu widzenia postępu technicznego w ówczesnym gazownictwie - nie miało to większego znaczenia. Zapewne istotną rolę w odpowiednim jego wykorzystaniu odgrywali ówcześni dyrektorzy obydwu przedsiębiorstw, Mertens i Teodorowicz, doskonale zorientowani w poziomie technologicznym ogólnoeuropejskiego gazownictwa początku XX w. Niezależnie od tego faktu, 
uwagę zwraca też ustalenie, iż we Lwowie, który aż do końca XIX w. posiadał gazownię prywatną, wraz z jej komunalizacją szybko i skutecznie zaczęto nadrabiać dekady zacofania technologicznego oraz braku inwestycji w miejską infrastrukturę gazową. Efekt był taki, że przed I wojną światową obydwa miasta dysponowały już zbliżoną długością sieci gazowej oraz liczbą publicznych latarni, choć wielkość produkcji bądź oddania gazu do sieci miejskiej była jednak znacznie większa w Poznaniu niż we Lwowie. Wynikało to prawdopodobnie z silniejszej pozycji gospodarczo-ekonomicznej nadwarciańskiego ośrodka.

\section{Bibliografia}

Dohnalowa T., Rozwój transportu w Wielkopolsce w latach 1815-1914, Warszawa Poznań 1976.

Dr. N. H. Schilling's Statistische Mittheilungen über die Gasanstalten Deutschlands, Österreichs und der Schweiz sowie einige Gasanstalten anderer Länder, München 1877.

Dr. N. H. Schilling's Statistische Mittheilungen über die Gasanstalten Deutschlands, Österreichs und der Schweiz sowie einige Gasanstalten anderer Länder, München 1896.

Dzieje Poznania w latach 1793-1918, red. J. Topolski, t. 2, cz. 1, Poznań 1994.

Dziurzyński A., 75-lecie Gazowni Miejskiej w Poznaniu, „Gaz i Woda” r. 11, 1931, nr 12, s. 293-301.

Gasanstalten. Julius Pintsch Aktiengesellschaft, Berlin 1915.

Klass von G., 100 Jahre Deutsche Continental Gas-Gesellschaft. Düsseldorf 1855-1955, Düsseldorf 1955.

Konopka J., Gazownictwo polskie i jego rozwój w świetle liczb i wykresów, Warszawa 1928.

Kowalczuk M., Rozwój terytorialny miasta, [w:] Miasto Lwów w okresie samorządu, Lwów 1896.

Łuczak L., W blasku błękitnego płomienia. 150 lat gazowni w Poznaniu, Poznań 2006.

Mertens H., Über die Licht- und Wasserwerke der Stadt Posen, „Journal für Gasbeleuchtung und Wasserversorgung" r. 47, 1904, nr 36, s. 823-825.

Pałat Z., Architektura a polityka. Gloryfikacja Prus i niemieckiej misji cywilizacyjnej w Poznaniu na początku XX wieku, Poznań 2011.

Puchta W., Powszechna Wystawa Krajowa we Lwowie w 1894 roku, Wrocław 2016.

Sroka T.Ł., Rada Miejska we Lwowie w okresie autonomii galicyjskiej 1870-1914, Kraków 2012.

Stettiner Chamottefabrik Aktiengesellschaft, vormals Didier. 50 Jahre Aktiengesellschaft 1872-1922, Berlin 1922.

Teodorowicz A., O rozwoju gazowni we Lwowie, „Przegląd Gazowniczy” r. 1, 1921, nr 1, s. 3-10.

Teodorowicz A., O rozwoju gazowni we Lwowie, „Przegląd Gazowniczy” r. 1, 1921, nr 2, s. 26-29.

Urbaniak M., Miejskie zakłady przemysłowe Wielkiego Księstwa Poznańskiego. Gazownie, t. 2 - Katalog, Łódź 2011.

Wnęk K., Zyblikiewicz L., Callahan E., Ludność nowoczesnego Lwowa w latach 18571938, Kraków 2006. 
Zarzycki A., Poznań. Gazownia w dziejach miasta. Tradycja i współczesność 1856-2012, Poznań 2013.

Dr hab. MIRON URBANIAK, prof. UWr, Instytut Historyczny Uniwersytetu Wrocławskiego, specjalizuje się w archeologii przemysłowej i ochronie dziedzictwa przemysłowo-technicznego Polski, autor licznych prac z zakresu historii i zabytków kolejnictwa, miejskich zakładów przemysłowych oraz hydrotechniki, ekspert Wojewódzkich Urzędów Ochrony Zabytków i członek PKN ICOMOS Polska. E-mail: miron.urbaniak@onet.eu 